\title{
EVALUATION OF YIELD AND HEALTHINESS OF TWENTY TABLE GRAPEVINE CULTIVARS GROWN IN CENTRAL POLAND
}

\author{
Jerzy LISEK \\ Research Institute of Horticulture \\ Konstytucji 3 Maja 1/3, 96-100 Skierniewice, Poland \\ Received: March 5, 2014; Accepted: June 11, 2014
}

\begin{abstract}
During the years 2008-2013, 20 table grape cultivars grown in Skierniewice (Central Poland) were assessed. Among the assessed cultivars, two - 'Chasselas Blanc' (standard) and 'Favorit' belonged to $V$. vinifera. Eighteen interspecific hybrids - 'Aron', 'Esther' ('Eszter'), 'Fanny', 'Flora', 'Galanth', 'Ganita', 'Garant', 'Katharina', 'Lidi', 'Lilla', 'Muscat Bleu', 'Nelly', 'Osella', 'Philipp', 'Rosetta', 'Rosina', 'Timur' and 'Verdelet' were bred in various European countries. Vines, grafted on 'Kober 5 BB' rootstock, were planted in 2007 and annually covered for winter. Taking into account productivity, quality of fruits, susceptibility to frost damage and fungal diseases, the Swiss 'Muscat Bleu' and German 'Garant' proved most suitable for cultivation in the conditions of Central Poland. Plants of all cultivars belonging to the group of interspecific hybrids were less susceptible to infections caused by fungal pathogens than plants of $V$. vinifera genotypes. The assessment of frost resistance based on the observation of those parts of bushes, which were not covered, showed high diversification among the interspecific hybrids.
\end{abstract}

Key words: Vitis vinifera L., Vitis sp., grapes, frost, fungal diseases

\section{INTRODUCTION}

Table grapes, consumed in the countries of Central Europe during summer, autumn and early winter, are primarily imported from Southern Europe (Jörger \& Engel 2003; Hajdu 2004). In the countries of Central and Eastern Europe, in central and northern states of America and in Canada, there has been a practice to cultivate table grapes locally in order to expand the market and provide farmers with new sources of income (Elfving et al. 1985; Jörger \& Engel 2003; Hajdu 2004). For this purpose, grapevines are cultivated mostly in ecological vineyards to cater for the needs of individual households, also sell the excess on the local market, and in home and recreational gardens (McEachern et al. 1982; Reisch et al. 2000; Basler 2002; Hajdu 2004; Abuzov 2009). The northern expansion of dessert grapevines is possible mainly thanks to advancement in breeding of cultivars of high quality of fruits and reliability of yield which however should be verified in field assessments (Pospíśilová 1981; Hajdu 2002). Special attention in breeding programmes conducted on large scale in Hungary, Germany, United States, Russia and Ukraine is directed toward obtaining genotypes characterised by high tolerance to main adverse biotic and abiotic factors - fungal diseases and frost (Clark \& Moore 1999; Kostrikin 2002; Kozma 2002; Hajdu 2004; Hajdu et al. 2007; Pavloušek 2007). In Central Poland, according to earlier studies most useful are interspecific hybrids bred in United States - 'Reliance', 'Canadice', in Canada 'Festivee'; in Ukraine - 'Ananasnyj Rannyj' (with V. labrusca) and in Hungary - 'Nero', 'Palatina' (Lisek 2010).

This study aimed to assess the most important functional traits, such as yield, fruit quality features, frost tolerance and healthiness of vines of 20 cultivars, mainly relatively new interspecific hybrids, which until now have not yet been subjected for methodological assessment in Poland. 


\section{MATERIAL AND METHODS}

The assessment was conducted in the field collection gathering 276 genotypes of the Research Institute of Horticulture in Skierniewice (latitude $51^{\circ} 57^{\prime} \mathrm{N}$, longitude $20^{\circ} 08^{\prime} \mathrm{E}$ ) located on a pseudopodsolic soil, slightly acidic (pH 6.3) and containing $1.3 \%$ of organic matter. Average monthly temperatures, rainfall and sum of active temperatures (SAT) - medium daily temperature higher than $10^{\circ} \mathrm{C}$, from 2008 to 2013 are presented in Tables 1 and 2. During the years 2008-2013, 20 table grape cultivars were assessed: two $V$. vinifera cultivars: standard 'Chasselas Blanc' and 'Favorit' (from Hungary), and interspecific hybrids bred in Hungary - 'Aron', 'Esther' ('Eszter'), 'Fanny', 'Flora', 'Lidi', 'Lilla'; in Germany - 'Galanth', 'Ganita', 'Garant', 'Nelly', 'Osella', 'Rosetta', 'Rosina', in Austria 'Katharina', 'Philipp'; in Switzerland - 'Muscat Bleu'; France - 'Verdelet' and in Russia - 'Timur'. Vines were grafted on $V$. berlandieri $\times V$. riparia 'Kober 5 BB' rootstock and planted in 2007. Each genotype was represented by three vines (counted as replications), planted at spacing of $2.5 \times 1 \mathrm{~m}$. Vines were formed as a low head with spur pruning (6-12 young shoots per bush). They were annually covered for winter with soil or straw (mounds of $0.4 \mathrm{~m}$ ). In each season, plants were treated twice with fungicides containing mancozeb and sulphur. In 2010-2013 the plants were treated additionally once more with a mixture of fungicides piraclostrobin + boscalid.

The following features were assessed: time of overall ripening, productivity of the bushes (marketable yield), weight of clusters and berries, soluble solids content and taste of fruits (together with aroma), susceptibility of vines to frost and fungal diseases. Clear or so-called neutral taste was assigned for grapes, without any distinct aroma. Mature grapes with typical colour of berry skin, firmness of flesh and brown seeds were harvested separately from each evaluated vine. All bunches was counted. One hundred berries collected from three representative bunches on each vine were weighted. Total soluble solids (TSS) content of a grape juice was determined by taking readings from an optical hand held refractometer PZO - RR 12, Poland. TSS was measured on three randomly chosen clusters from each bush. Juice was squeezed from 15 berries from each cluster (berries were gathered equally from the base, the middle and the top of bunch). Statistic calculations were conducted with the use of arithmetical means of TSS.

Frost damage of uncovered parts of bushes was assessed in March (during pruning) according to a 5 -grade scale. Following criteria were used: 1 lack of damage, 2 - frozen buds not exceeding $10 \%, 3-11-50 \%$ of frozen buds, $4-$ more than $50 \%$ of frozen buds and damage on the one-year shoots, 5 - death of skeletal parts of bushes. Assessment of damage caused by downy (Plasmopara viticola (Berk. et Curtis ex de Bary) Berl. et de Toni) and powdery mildew (Uncinula necator (Schw.) Burr.) was conducted directly before harvest on each plot in 5-grade scale. The following criteria were used: 1 - lack of damage, 2 - less than $20 \%$ of leaves and vines (young shoots) infested by mildew, $3-21-50 \%$ of infested leaves and vines, 4 - heavily infested leaves and vines, together with slight (up to 10\%) infestation of berries, 5 - heavily infested leaves, shoots (more than 50\%) and berries (more than $10 \%$ ). Occurrence of excoriose (Phomopsis viticola Sacc.), which causes death of wood and buds, was assessed in the period of pruning (first and second week of March). A 5-grade scale was applied: 1 - lack of damage, 2 - damage up to $20 \%, 3-21-50 \%, 4-51-100 \%$ of shoots internodes infested, 5 - death of skeletal parts of bushes and whole plants. Infestation was assessed on the basis of both the colour of shoots (change from brown to grey) and the excoriose visible on cross-sections of older shoots. Susceptibility to decay caused by grey mould (Botryotinia fuckeliana (de Bary) Whetzel) was assessed during harvest, in six-grade scale: 1 - lack of damage, 2 - damage up to $3 \%, 3-4-10 \%, 4-11-25 \%, 5-26-60 \%, 6$-more than $60 \%$ of fruit infested. Evaluation methods of damages caused by frost and fungus were developed by the author.

Yield, weight of clusters and berries, soluble solids content data, frost and fungal damages were analysed statistically using analysis of variance. The significance of the means was evaluated using Duncan's test at the $5 \%$ level. 
Table 1. Mean month air temperature and SAT $\left({ }^{\circ} \mathrm{C}\right)$, Skierniewice, 2008-2013 years

\begin{tabular}{|c|c|c|c|c|c|c|c|c|c|c|c|c|c|}
\hline \multirow{2}{*}{ Year } & \multicolumn{12}{|c|}{ Months } & \multirow{2}{*}{ SAT } \\
\hline & $\mathrm{I}$ & II & III & IV & $\mathrm{V}$ & VI & VII & VIII & IX & $\mathrm{X}$ & $\mathrm{XI}$ & XII & \\
\hline 2008 & 1.1 & 2.9 & 3.4 & 8.3 & 12.6 & 17.4 & 18.6 & 18.1 & 12.0 & 9.5 & 5.0 & 1.1 & 2519 \\
\hline 2009 & -3.1 & -1.2 & 2.4 & 10.0 & 12.5 & 15.3 & 18.9 & 17.7 & 14.2 & 6.3 & 5.5 & 6.3 & 2531 \\
\hline 2010 & -8.3 & -2.4 & 3.8 & 8.8 & 12.4 & 16.3 & 20.4 & 18.7 & 11.5 & 5.0 & 5.3 & -6.1 & 2422 \\
\hline 2011 & -0.6 & -4.3 & 3.1 & 10.0 & 13.6 & 17.8 & 17.3 & 18.1 & 14.4 & 8.4 & 2.4 & 2.4 & 2718 \\
\hline 2012 & -1.2 & -6.5 & 4.8 & 9.0 & 14.7 & 16.7 & 20.2 & 18.6 & 14.2 & 7.6 & 5.4 & -2.9 & 2730 \\
\hline 2013 & -3.5 & -1.0 & -2.3 & 7.5 & 14.3 & 17.5 & 19.1 & 18.4 & 11.5 & 9.4 & 5.3 & 2.4 & 2553 \\
\hline $\begin{array}{c}\text { Means in } \\
1991-2010\end{array}$ & -1.6 & -0.4 & 2.8 & 9.2 & 13.7 & 16.8 & 19.2 & 18.2 & 13.9 & 8.2 & 3.3 & -0.1 & - \\
\hline
\end{tabular}

Table 2. Rainfall (mm), Skierniewice, 2008-2013 years

\begin{tabular}{|c|c|c|c|c|c|c|c|c|c|c|c|c|c|}
\hline \multirow{2}{*}{ Year } & \multicolumn{12}{|c|}{ Months } & \multirow{2}{*}{$\begin{array}{c}\text { Year } \\
\text { amount }\end{array}$} \\
\hline & I & II & III & IV & V & VI & VII & VIII & IX & X & XI & XII & \\
\hline 2008 & 72 & 17 & 49 & 23 & 63 & 12 & 52 & 92 & 55 & 26 & 21 & 47 & 529 \\
\hline 2009 & 19 & 21 & 38 & 11 & 68 & 145 & 77 & 73 & 29 & 83 & 59 & 42 & 667 \\
\hline 2010 & 0 & 22 & 40 & 16 & 129 & 63 & 77 & 123 & 100 & 4 & 83 & 22 & 680 \\
\hline 2011 & 17 & 29 & 14 & 73 & 51 & 45 & 263 & 62 & 2 & 5 & 1 & 31 & 592 \\
\hline 2012 & 2 & 20 & 18 & 52 & 18 & 65 & 52 & 63 & 41 & 51 & 23 & 0 & 406 \\
\hline 2013 & 0 & 3 & 4 & 43 & 100 & 153 & 6 & 18 & 48 & 15 & 19 & 14 & 423 \\
\hline $\begin{array}{c}\text { Means in } \\
1991-2010\end{array}$ & 29 & 26 & 40 & 40 & 65 & 67 & 68 & 54 & 47 & 38 & 39 & 30 & 542 \\
\hline
\end{tabular}

\section{RESULTS AND DISCUSSION}

The assessing of table grape cultivars showed their substantial differences in the shape and colour of the berries as well as in most important functional traits, such as time of ripening and the quality of fruits, productivity, resistance of the bushes to frost and fungal diseases (Tables 3, 4, 5). Grapes of ' $\mathrm{Fa}$ vorit' were gathered first. The unripe grapes of 'Philipp' were gathered last (Table 3). Grapes of greatest weight were harvested from the bushes of 'Aron', 'Fanny', 'Lilla' and 'Flora'. Weight of berries of 'Katharina' and 'Timur' was greater than berries of all other cultivars. The highest TSS content was recorded in the berries of 'Ganita', next to the berries of 'Garant' and 'Galanth'. Grapes of the lowest TSS content were harvested from the vines of 'Philipp'. Yield of 'Muscat Bleu' was higher in the whole examined period than all other assessed cultivars, including the standard cv. 'Chasselas Blanc' (Table 4). The best frost tolerance of the wintering buds showed 'Rosina', 'Muscat Bleu', 'Garant' and 'Verdelet' (Table 5). Greatest frost damage suffered the buds of 'Favorit'. Best resistance to downy and powdery mildew, excoriose and grey mould presented the bushes of 'Muscat Bleu' and 'Garant' (Table 5). Grapes of the 'Muscat Bleu' and 'Timur' were characterised by soft muscat aroma. Taste of fruits of other cultivars was described as clear. The cultivar 'Esther' tended to colour unevenly and produce small, seedless berries. Berries of the cultivar 'Timur's burst if the summer was humid.

Yielding of grapevine depends on genetic factors that encode fruitfulness (including fertility of vines under spur pruning of 1 -year shoots and alternate bearing), age, healthiness, nutrition of plants and climate conditions (especially temperature and rainfall). Weather conditions influenced flower and fruit development in current year and differentiation of inflorescence primordia for the next year. Long-term years' summary yields should be considered as a key indicator in the field evaluation of cultivars in terms of their usefulness for cultivation. Analysing the yield in a particular year is essential to identify factors limiting cropping. 
Table 3. Chosen fruit traits of 20 table grapevine cultivars. Skierniewice, 2008-2013

\begin{tabular}{llcllc}
\hline $\begin{array}{c}\text { Cultivars in alphabetical } \\
\text { order (skin colour) }\end{array}$ & $\begin{array}{c}\text { Berry } \\
\text { shape** }\end{array}$ & $\begin{array}{c}\text { Time of rip- } \\
\text { ening }\end{array}$ & $\begin{array}{c}\text { Weight of } \\
\text { cluster (g) }\end{array}$ & $\begin{array}{c}\text { Weight of 100 } \\
\text { berries (g) }\end{array}$ & $\begin{array}{c}\text { Total soluble } \\
\text { solids (\%) }\end{array}$ \\
\hline Aron (B) & SE & 8.10. & $308 \mathrm{e}$ & $394 \mathrm{~h}$ & $15.9 \mathrm{~b}-\mathrm{e}$ \\
Chasselas Blanc (B) & R & 21.09. & $144 \mathrm{abc}$ & $291 \mathrm{cde}$ & $16.6 \mathrm{c}-\mathrm{f}$ \\
Esther (N) & R-SE & 13.09. & $182 \mathrm{bcd}$ & $362 \mathrm{gh}$ & $15.4 \mathrm{bcd}$ \\
Fanny (B) & R-SE & 9.10. & $281 \mathrm{e}$ & $524 \mathrm{i}$ & $14.3 \mathrm{ab}$ \\
Favorit (B) & R & 6.09. & $108 \mathrm{ab}$ & $365 \mathrm{gh}$ & $16.5 \mathrm{c}-\mathrm{f}$ \\
Flora (R) & R-SE & 8.10. & $249 \mathrm{de}$ & $390 \mathrm{~h}$ & $16.5 \mathrm{c}-\mathrm{f}$ \\
Galanth (N) & SE & 22.09. & $129 \mathrm{abc}$ & $263 \mathrm{bcd}$ & $19.2 \mathrm{gh}$ \\
Ganita (R) & R-SE & 21.09. & $139 \mathrm{abc}$ & $251 \mathrm{abc}$ & $19.8 \mathrm{~h}$ \\
Garant (B) & SE & 17.09. & $167 \mathrm{abc}$ & $337 \mathrm{fg}$ & $19.6 \mathrm{gh}$ \\
Katharina (R) & SE-OO & 9.10. & $140 \mathrm{abc}$ & $595 \mathrm{j}$ & $15.0 \mathrm{bc}$ \\
Lidi (R) & SE & 10.10. & $148 \mathrm{abc}$ & $399 \mathrm{~h}$ & $15.4 \mathrm{bcd}$ \\
Lilla (B) & SE & 1.10. & $261 \mathrm{e}$ & $540 \mathrm{i}$ & $16.8 \mathrm{def}$ \\
Muscat Bleu (N) & SE & 11.09. & $181 \mathrm{bcd}$ & $343 \mathrm{fg}$ & $15.8 \mathrm{~b}-\mathrm{e}$ \\
Nelly (R) & R-SE & 2.10. & $169 \mathrm{abc}$ & $303 \mathrm{def}$ & $17.2 \mathrm{ef}$ \\
Osella (N) & SE & 17.09. & $106 \mathrm{ab}$ & $233 \mathrm{ab}$ & $18.1 \mathrm{fg}$ \\
Philipp (N) & OO & 11.10. & $191 \mathrm{~cd}$ & $219 \mathrm{a}$ & $13.2 \mathrm{a}$ \\
Rosetta (R) & R & 28.09. & $128 \mathrm{abc}$ & $314 \mathrm{ef}$ & $17.4 \mathrm{ef}$ \\
Rosina (N) & SE & 20.09. & $102 \mathrm{a}$ & $222 \mathrm{a}$ & $18.1 \mathrm{fg}$ \\
Timur (B) & LE-O & 19.09. & $112 \mathrm{ab}$ & $582 \mathrm{j}$ & $16.3 \mathrm{cde}$ \\
Verdelet (B) & SE & 30.09. & $158 \mathrm{abc}$ & $268 \mathrm{bcd}$ & $17.5 \mathrm{ef}$ \\
\hline
\end{tabular}

Explanation: * Colour of berry skin: B (Blanc) - yellow-green; R - rose-red; N (Noir) - blue-black ** Shape of berry: $\mathrm{R}$ - roundish; $\mathrm{SE}$ - short elliptic; $\mathrm{O}$ - ovate; $\mathrm{OO}$ - obtuse-ovate; LE - long elliptic Averages marked by the same letter do not differ significantly at the $\mathrm{p}=0.05$ according to Duncan test

Table 4. Yielding of 20 table grapevine cultivars. Skierniewice, 2008-2013

\begin{tabular}{|c|c|c|c|c|c|c|c|}
\hline \multirow[b]{2}{*}{ Cultivar } & \multicolumn{7}{|c|}{ Marketable fruit yield (kg/vine) } \\
\hline & 2008 & 2009 & 2010 & 2011 & 2012 & 2013 & $\begin{array}{c}\text { Total in } \\
2008-2013\end{array}$ \\
\hline Aron & $0.96 \mathrm{~cd}$ & $2.16 \mathrm{hi}$ & $1.21 \mathrm{de}$ & $2.01 \mathrm{hi}$ & $0.92 \mathrm{efg}$ & $2.67 \mathrm{f}$ & $9.93 \mathrm{~h}$ \\
\hline Chasselas Blanc & $0.72 \mathrm{bc}$ & $1.6 \mathrm{f}$ & $1.55 \mathrm{f}$ & $1.10 \mathrm{de}$ & $0.54 \mathrm{bcd}$ & $0.74 \mathrm{abc}$ & $6.25 \mathrm{ef}$ \\
\hline Esther & $1.37 \mathrm{e}$ & $0.74 \mathrm{bcd}$ & $0.41 \mathrm{ab}$ & $0.47 \mathrm{~b}$ & $0.51 \mathrm{bcd}$ & $0.85 \mathrm{a}-\mathrm{d}$ & $4.35 \mathrm{bc}$ \\
\hline Fanny & $1.86 \mathrm{f}$ & $2.51 \mathrm{j}$ & $1.13 \mathrm{de}$ & $0.97 \mathrm{~cd}$ & 0.68 cde & $1.07 \mathrm{~b}-\mathrm{e}$ & $8.22 \mathrm{~g}$ \\
\hline Favorit & $0.22 \mathrm{a}$ & $0.32 \mathrm{a}$ & $0.24 \mathrm{a}$ & $0.11 \mathrm{a}$ & $0.19 \mathrm{a}$ & $0.37 \mathrm{a}$ & $1.45 \mathrm{a}$ \\
\hline Flora & $0.3 \mathrm{a}$ & $3.36 \mathrm{k}$ & $0.73 \mathrm{bc}$ & $1.63 \mathrm{fg}$ & $1.13 \mathrm{~g}$ & $1.16 \mathrm{cde}$ & $8.31 \mathrm{~g}$ \\
\hline Galanth & $0.66 \mathrm{~b}$ & $0.48 \mathrm{ab}$ & $1.16 \mathrm{de}$ & $0.68 \mathrm{bc}$ & $0.39 \mathrm{abc}$ & $2.57 \mathrm{f}$ & 5.94 ef \\
\hline Ganita & $1.34 \mathrm{e}$ & $0.6 \mathrm{a}-\mathrm{d}$ & $0.39 a b$ & $0.65 \mathrm{bc}$ & $0.8 \mathrm{def}$ & $0.59 \mathrm{ab}$ & $4.37 \mathrm{bc}$ \\
\hline Garant & $0.91 \mathrm{bcd}$ & $1.25 \mathrm{e}$ & 1.4 ef & $1.81 \mathrm{gh}$ & 0.9 efg & $4.02 \mathrm{~g}$ & $10.3 \mathrm{~h}$ \\
\hline Katharina & $0.35 \mathrm{a}$ & $0.6 \mathrm{a}-\mathrm{d}$ & $0.54 \mathrm{ab}$ & $2.01 \mathrm{hi}$ & $0.39 \mathrm{abc}$ & $2.65 \mathrm{f}$ & $6.54 \mathrm{f}$ \\
\hline Lidi & $0.22 \mathrm{a}$ & $1.98 \mathrm{gh}$ & $0.42 \mathrm{ab}$ & $0.72 \mathrm{bc}$ & $0.45 \mathrm{abc}$ & $0.85 \mathrm{a}-\mathrm{d}$ & $4.64 \mathrm{~cd}$ \\
\hline Lilla & $2.48 \mathrm{~g}$ & $2.35 \mathrm{ij}$ & $1.53 \mathrm{f}$ & $1.08 \mathrm{de}$ & $0.52 \mathrm{bcd}$ & $1.58 \mathrm{e}$ & $9.54 \mathrm{~h}$ \\
\hline Muscat Bleu & $2.46 \mathrm{~g}$ & $2.52 \mathrm{j}$ & $2.35 \mathrm{~g}$ & $2.31 \mathrm{i}$ & 0.65 cde & $4.07 \mathrm{~g}$ & $14.4 \mathrm{i}$ \\
\hline Nelly & $1.17 \mathrm{de}$ & $2.39 \mathrm{ij}$ & $0.54 \mathrm{ab}$ & $1.1 \mathrm{de}$ & $0.55 \mathrm{bcd}$ & $0.71 \mathrm{abc}$ & $6.46 \mathrm{f}$ \\
\hline Osella & $0.36 \mathrm{a}$ & $0.89 \mathrm{~d}$ & $0.64 \mathrm{~b}$ & $0.71 \mathrm{bc}$ & $0.41 \mathrm{abc}$ & $0.59 \mathrm{ab}$ & $3.6 \mathrm{~b}$ \\
\hline Philipp & $0.36 \mathrm{a}$ & $1.67 \mathrm{fg}$ & $1.02 \mathrm{~cd}$ & $0.66 \mathrm{bc}$ & $0.32 \mathrm{ab}$ & $1.4 \mathrm{de}$ & $5.43 \mathrm{de}$ \\
\hline Rosetta & $0.33 \mathrm{a}$ & $1.68 \mathrm{fg}$ & $0.5 \mathrm{ab}$ & $1.37 \mathrm{ef}$ & $1.07 \mathrm{fg}$ & $1.33 \mathrm{de}$ & $6.28 \mathrm{ef}$ \\
\hline Rosina & $0.25 \mathrm{a}$ & $0.82 \mathrm{~cd}$ & $0.53 \mathrm{ab}$ & $1.1 \mathrm{de}$ & $0.8 \mathrm{def}$ & $1.0 \mathrm{bcd}$ & $4.5 \mathrm{c}$ \\
\hline Timur & $0.35 \mathrm{a}$ & $0.5 \mathrm{abc}$ & $0.68 \mathrm{~b}$ & $1.2 \mathrm{de}$ & $0.4 \mathrm{abc}$ & $2.54 \mathrm{f}$ & $5.67 \mathrm{ef}$ \\
\hline Verdelet & $0.72 \mathrm{bc}$ & $0.93 \mathrm{~d}$ & $1.65 \mathrm{f}$ & $1.31 \mathrm{def}$ & $1.72 \mathrm{~h}$ & $1.36 \mathrm{de}$ & $7.69 \mathrm{~g}$ \\
\hline
\end{tabular}

Explanation: Averages marked by the same letter do not differ significantly at the $\mathrm{p}=0.05$ according to Duncan test 
Table 5. Winter hardiness and healthiness of vines of 20 table grape cultivars. Skierniewice, 2008-2013

\begin{tabular}{lccccc}
\hline \multicolumn{1}{c}{ Cultivar } & $\begin{array}{c}\text { Winter } \\
\text { hardiness } \\
\text { (scale 1-5) }\end{array}$ & $\begin{array}{c}\text { Susceptibility to } \\
\text { downy mildew } \\
\text { (scale 1-5) }\end{array}$ & $\begin{array}{c}\text { Susceptibility to } \\
\text { powdery mildew } \\
\text { (scale 1-5) }\end{array}$ & $\begin{array}{c}\text { Susceptibility to } \\
\text { excoriose } \\
\text { (scale 1-5) }\end{array}$ & $\begin{array}{c}\text { Susceptibility to } \\
\text { grey mould } \\
\text { (scale 1-6) }\end{array}$ \\
\hline Aron & $4.4 \mathrm{~d}-\mathrm{g}$ & $1.3 \mathrm{ab}$ & $1.7 \mathrm{bc}$ & $2.5 \mathrm{c}$ & $3.2 \mathrm{f}$ \\
Chasselas Blanc & $3.6 \mathrm{c}$ & $3.7 \mathrm{f}$ & $3.5 \mathrm{~g}$ & $1.5 \mathrm{a}$ & $2.0 \mathrm{bc}$ \\
Esther & $4.2 \mathrm{c}-\mathrm{f}$ & $2.0 \mathrm{c}$ & $3.0 \mathrm{ef}$ & $2.5 \mathrm{c}$ & $1.5 \mathrm{a}$ \\
Fanny & $4.6 \mathrm{efg}$ & $2.5 \mathrm{~d}$ & $2.8 \mathrm{de}$ & $4.0 \mathrm{f}$ & $2.3 \mathrm{~cd}$ \\
Favorit & $5.0 \mathrm{~g}$ & $3.8 \mathrm{f}$ & $4.2 \mathrm{~h}$ & $3.0 \mathrm{~d}$ & $2.3 \mathrm{~cd}$ \\
Flora & $4.4 \mathrm{~d}-\mathrm{g}$ & $2.5 \mathrm{~d}$ & $2.8 \mathrm{de}$ & $3.5 \mathrm{e}$ & $2.5 \mathrm{~d}$ \\
Galanth & $3.6 \mathrm{c}$ & $2.0 \mathrm{c}$ & $2.0 \mathrm{c}$ & $1.5 \mathrm{a}$ & $2.3 \mathrm{~cd}$ \\
Ganita & $4.0 \mathrm{cde}$ & $2.0 \mathrm{c}$ & $3.0 \mathrm{ef}$ & $2.0 \mathrm{~b}$ & $3.0 \mathrm{ef}$ \\
Garant & $2.6 \mathrm{ab}$ & $1.0 \mathrm{a}$ & $1.3 \mathrm{ab}$ & $1.5 \mathrm{a}$ & $1.8 \mathrm{ab}$ \\
Katharina & $4.8 \mathrm{fg}$ & $2.0 \mathrm{c}$ & $2.5 \mathrm{~d}$ & $4.0 \mathrm{f}$ & $2.3 \mathrm{~cd}$ \\
Lidi & $4.4 \mathrm{~d}-\mathrm{g}$ & $2.0 \mathrm{c}$ & $2.8 \mathrm{de}$ & $4.0 \mathrm{f}$ & $3.0 \mathrm{ef}$ \\
Lilla & $4.6 \mathrm{efg}$ & $2.7 \mathrm{de}$ & $3.0 \mathrm{ef}$ & $3.0 \mathrm{~d}$ & $3.0 \mathrm{ef}$ \\
Muscat Bleu & $2.4 \mathrm{a}$ & $1.0 \mathrm{a}$ & $1.2 \mathrm{a}$ & $1.8 \mathrm{ab}$ & $1.5 \mathrm{a}$ \\
Nelly & $4.6 \mathrm{efg}$ & $2.8 \mathrm{de}$ & $2.7 \mathrm{de}$ & $4.0 \mathrm{f}$ & $2.3 \mathrm{~cd}$ \\
Osella & $3.0 \mathrm{~b}$ & $2.5 \mathrm{~d}$ & $3.0 \mathrm{ef}$ & $1.7 \mathrm{ab}$ & $2.0 \mathrm{bc}$ \\
Philipp & $4.8 \mathrm{fg}$ & $2.5 \mathrm{~d}$ & $2.7 \mathrm{de}$ & $3.5 \mathrm{e}$ & $2.5 \mathrm{~d}$ \\
Rosetta & $3.8 \mathrm{~cd}$ & $3.0 \mathrm{e}$ & $3.3 \mathrm{fg}$ & $2.0 \mathrm{~b}$ & $2.0 \mathrm{bc}$ \\
Rosina & $2.4 \mathrm{a}$ & $2.8 \mathrm{de}$ & $2.8 \mathrm{de}$ & $1.7 \mathrm{ab}$ & $2.0 \mathrm{bc}$ \\
Timur & $3.8 \mathrm{~cd}$ & $2.5 \mathrm{~d}$ & $2.7 \mathrm{de}$ & $2.5 \mathrm{c}$ & $2.5 \mathrm{~d}$ \\
Verdelet & $2.6 \mathrm{ab}$ & $1.5 \mathrm{~b}$ & $2.5 \mathrm{~d}$ & $3.5 \mathrm{e}$ & $2.7 \mathrm{de}$ \\
\hline
\end{tabular}

Explanation: Susceptibility to frost injuries (average in winters 2008/2009, 2009/2010, 2010/2011, 2011/2012, 2012/2013) and fungal diseases: 1 - resistant, 5-6 - susceptible.

Averages marked by the same letter do not differ significantly at the $p=0.05$ according to Duncan test.

In the course of the study, the following minimum winter temperatures were noted at the height of $2 \mathrm{~m}$ : $-23.0{ }^{\circ} \mathrm{C}(6.01 .2009) ;-28.1{ }^{\circ} \mathrm{C}$ (26.01.2010); $-22.3{ }^{\circ} \mathrm{C}(22.02 .2011) ;-23.3{ }^{\circ} \mathrm{C}$ (04.02.2012); $-21.4^{\circ} \mathrm{C}(24.03 .2013)$. Frost damage of vines after the winter $2009 / 2010$ was greater than after the winter 2012/2013, but mean, 5 years' frost injury results described well enough differences in frost resistance between cultivars. Extremely low winter temperature was not a factor that would influence the yield of the bushes, which were covered for winter in this assessment. In the conditions of Skierniewice, in the four seasons, yield of the bushes was reduced by spring frosts, which occurred after the start of vegetation and damaged developing buds and young shoots. Below are given minimal temperatures after the vegetation started and the date of the occurrence: $-4.0{ }^{\circ} \mathrm{C}$ (20.04.2009), $-1.8{ }^{\circ} \mathrm{C}(15.05 .2009) ;-2.5{ }^{\circ} \mathrm{C}$ (25.04.2010); $-1.5^{\circ} \mathrm{C}$ (20.04.2011 and 4.05.2011); $-1.5^{\circ} \mathrm{C}$ (8.05.2012 and 18.05.2012). Good yield of the bushes of 'Lilla' and 'Muscat Bleu' in the year following the planting shows high fruitfulness of those cultivars.

The average SAT in Skierniewice in years 2008-2013 amounted to $2569{ }^{\circ} \mathrm{C}$. SAT varied from $2422{ }^{\circ} \mathrm{C}$ in 2010 to $2730^{\circ} \mathrm{C}$ in 2012 . The year 2010 was a chill one, with low SAT values. The summer of 2011 brought an unprecedentedly abundant rainfall (263 $\mathrm{mm}$ in July) and the vine roots were 2 weeks under water. Low yields of bushes of the majority of cultivars in 2012 was a result of spring frosts and the flooding of vine roots which occurred in the previous year. The warm year 2012 with high SAT values created favourable conditions for the differentiation of inflorescence in the following year (2013), for the bushes that were not loaded with fruits. Yield of the bushes of 'Muscat Bleu' and 'Garant' was in 2013 highest during the whole period of the assessment. In the same year, part of the marketable yield of the bushes of cultivars not resistant and medium-resistant to fungal diseases, such as 'Chasselas Blanc', 'Favorit', 'Ganita' and 'Lilla' was lost. Good yielding of the bushes of 
'Muscat Bleu' and 'Garant' was a result of genetically conditioned fertility, positive reaction of the bushes to spur pruning of 1-year shoots and satisfactory resistance to fungal diseases.

Results obtained in this study showed that the majority of cultivars and traits, such as susceptibility to frost damage and fungal pathogens, size of clusters and berries and mutual relations between cultivars in the ripening season, confirmed data obtained in other countries. 'Muscat Bleu' was in Central Poland as useful in cultivation, as in the conditions of Switzerland, Germany, south-west Russia and Ukraine (Basler 2002; Jörger \& Engel 2003; Abuzov 2009). Grapes of 'Muscat Bleu' and 'Garant' in Skierniewice reached overall ripeness after September 10th, at least 1 week later than in southwest Germany (Jörger \& Engel 2003). Bushes of the cultivar 'Favorit', in Skierniewice and Slovakia alike (Pospíśilová 1981), proved to be susceptible to frost, downy and powdery mildew. Climatic differences between Poland and other neighbouring countries indicate the necessity of experimental verification of data concerning the cultivars. Due to climatic differences, fruits of 'Timur' did not ripen in Central Poland as early as in Ukraine, and more than 30\% of wintering buds of the cultivar freeze in temperature from -22 to $-25{ }^{\circ} \mathrm{C}$, which they tolerate in Ukraine (Kostrikin 2002).

Interspecific hybrids showed higher resistance to fungal diseases than 'Chasselas Blanc' and 'Favorit', belonging to $V$. vinifera. Results proving that dessert interspecific hybrids are more resistant to powdery mildew than $V$. vinifera cultivars were obtained also in Czech Republic (Pavloušek 2007). Frost tolerance of the hybrids varied, but for most of them frosty winters, regularly occurring in Poland, could not guarantee overwintering. Hungarian interspecific hybrids 'Lilla' and 'Fanny' characterised by good fertility, attractive clusters and berries, were affected by fungal disease at limited chemical protection. Intensive rainfalls that were noted, e.g. in June 2009 (147 mm), in July 2011 (263 mm), in May $2013(100 \mathrm{~mm})$, in June $2013(153 \mathrm{~mm})$ posed a threat of fungal diseases even in the case of those cultivars, which are described in foreign literature as moderately resistant. The French hybrid 'Verdelet' proved insufficiently tolerant/resistant to frost and excoriose in Polish conditions and in the Canadian region of Ontario likewise (Elfving et al. 1985). Cultivar 'Verdelet' yields unfailingly in regions of warmer climate, such as Texas in United States (McEachern et al. 1982).

As regards the most important functional traits, hybrids 'Muscat Bleu' and 'Garant', with firm (nonslipskin) flesh of berries, should be considered as most useful in cultivation for Central Poland.

\section{CONCLUSIONS}

1. Cultivation of table grapes in Central Poland and other regions characterised by similar climate is limited by winter and spring frosts as well as by low sum of active temperatures.

2. In Central Poland, from the 20 assessed genotypes, 'Muscat Bleu' and 'Garant' are most reliable for cultivation.

3. Interspecific hybrids Muscat Bleu' and 'Garant', characterised by higher tolerance to adverse biotic and abiotic factors than the $V$. vinifera cultivars, can be recommended for prospective trials and growing, especially in ecological vineyards and home gardens.

\section{REFERENCES}

Abuzov M. 2009. Atlas sieviernovo vinograda. Smolensk, KFH Pitomnik Publishing, 165 p. [in Russian]

Basler P. 2002. Ungespritzte einheimische Tafeltrauben. Schweiz. Z. Obst Weinbau 138(7): 169-170. [in German]

Clark J.R., Moore J.N. 1999. 'Neptune' seedless grape. HortScience 34(7): 1300-1302.

Elfving D.C., Dale A., Fisher K.H., Miles N., Tehrani G. 1985. Fruit cultivars. Ontario Min. Agr. Food Publ. 430, 82 p.

Hajdu E. 2002. Table grape (Vitis vinifera L.) breeding and results in Hungary. Int. J. Hort. Sci. 81: 25-29.

Hajdu E. 2007. Breeding of table grape varieties in Hungary and beyond our national borders. Hung. Agric. Res. 4: 4-9.

Hajdu E., Hajós L., Ésik A., Saskői É. 2007. Hungarian qualified PIWI table grape varieties for eco-vine growing. Proceedings XXX OIV 
Conference, Budapest. www.oiv2007.hu/documents/viticulture/PIWI_varieties_Hajdu.pdf

Jörger V., Engel R. 2003. Tafeltrauben bieten auch für den heimischen Anbau eine Chance. Der Badishe Winzer 3: 37-42. [in German]

Kostrikin I.A. 2002. Ustojcziwyje sorta vinograda genofonda SNG. Rostov-Odessa-Zaporože, VVUR Publishing, 56 p. [in Russian]

Kozma P. Jr. 2002. Resistant grape varieties originating from Franco-American hybrids in Hungary. Int. J. Hort. Sci. 81: 47-50.

Lisek J. 2010. Yielding and healthiness of chosen table cultivars from the grapevine collection in Skierniewice. Zesz. Probl. Post. Nauk Rol. 555: $55-$ 62. [in Polish with English abstract]
McEachern G.R., Stein L.A., Gan P., Lipe W.N., Stockton L.A., Helmers S.G. 1982. Texas vineyard guide. Texas Agricultural Experiment Station, $44 \mathrm{p}$

Pavloušek P. 2007. Evaluation of resistance to powdery mildew in grapevine genetic resources. J. Cent. Eur. Agric. 8(1): 105-114.

Pospíšilová D. 1981. Ampelografia ČSSR. Bratislava, Priroda Publishing, 347 p. [in Slovak]

Reisch B.I., Pool R.M., Peterson D.V., Martens M.-H. 1993. Table grape varieties for cool climates. Information Bulletin 234, 9 p. Cornell Cooperative Extension, Cornell University. 